Mini Review

\section{Antifungal activity of epecific plant essential oils against fusarium graminearum}

\section{Esma Özsoy, Buket Kesercan and Emre Yörük*}

Department of Molecular Biology and Genetics, Faculty of Arts and Sciences, Istanbul Yeni Yuzyil University, Cevizlibag, Istanbul 34010, Turkey

\section{Summary}

Fusarium graminearum is one of the most popular phytopathogens of cereals worldwide. F. graminearum is the major causal agent of head blight of wheat and barley. Disease-resistant cultivar development, antagonistic microorganism usage and fungicide treatment are the most common strategies in head blight management strategies. However, these methods have some important disadvantages. The use of plant-derived essential oil against $F$. graminearum seems to be a promising approach due to the recent researches. This review summarizes the potential use of essential oils to fight against $F$. graminearum.

\section{Introduction}

Fusarium graminearum (telemorph Gibberella zeae) is a major phytopathogen causing diseases in cereals with great economic impacts as wheat (Triticum aestivum L.), barley (Hordeum vulgare L.), corn (Zea mays L.), and rice (Oryza sativa L.). F. graminearum is a taxonomical member from the division Ascomycota, of the class Sordariomycetidae, the order Hypocreales. It is a hemibiotrophic fungus with asexual and sexual stages. The natural habitat for this species is soil, and the $24-32{ }^{\circ} \mathrm{C}$ is the optimal temperature range for F. graminearum $[1,2]$. This species, which was reported to be common in humidity regions in the past years, has now been spreading gradually due to global climate changes and has also been isolated from regions with different climatic characteristics. F. graminearum has been reported to be a major pathogen of head blight and crown rot of wheat, barley and maize (Figure 1) worldwide [3]. F. graminearum infections lead to serious economic losses and mycotoxin contaminations in cereal crops. The decrease in quality and quantity of cereals

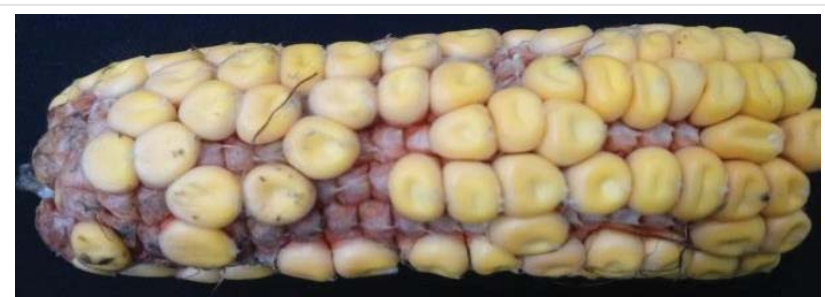

Figure 1: F. graminearum infected maize stalk.

\section{More Information}

*Address for Correspondence: Emre Yörük, Department of Molecular Biology and Genetics, Faculty of Arts and Sciences, Istanbul Yeni Yuzyil University, Cevizlibag, Istanbul 34010, Turkey, Tel: +90 4445001/3505; Email: emre.yoruk@yeniyuzyil.edu.tr; emreyoruk1@hotmail.com

Submitted: 14 October 2020

Approved: 24 October 2020

Published: 31 October 2020

How to cite this article: Özsoy E, Kesercan B, Yörük E. Antifungal activity of specific plant essential oils against fusarium graminearum. J Plant Sci Phytopathol. 2020; 4: 060-062.

DOI: 10.29328/journal.jpsp.1001052

ORCID: https://orcid.org/0000-0003-2770-0157

Copyright: @ 2020 Özsoy E, et al. This is an open access article distributed under the Creative Commons Attribution License, which permits unrestricted use, distribution, and reproduction in any medium, provided the original work is properly cited.

Check for updates

OPEN ACCESS could reach up to $70 \%$, and billions of dollars losses have been reported from wheat, barley and maize fields [2,4-6].

F.graminearum is animportantphytotoxin producerfungus. It produces several mycotoxins, including deoxynivalenol and acetylated derivatives, nivalenol, zearalenone, fusarin $\mathrm{C}$, and others [7]. The haploid chromosome number of this species is four $(n=4)$ and the genome size is approximately $36.1 \mathrm{Mb}$. It was also shown that the guanine-cytosine $\%$ content is $\%$ 48.33 , the gene number was 13,701 , and the exon number was 37,575. According to closely related species, such as Aspergillus sp., Neurospora sp., and Magnaporthe sp., high of levels Single Nucleotide Polymorphism (SNP) of genes encoding these proteins was revealed via bioinformatics analysis. Currently, more than 10,000 records are located in EST databases $[2,8]$.

In the struggle against $F$. graminearum, the development of pathogen-resistant plant lines, the use of antagonist microorganisms, and the use of fungicides have been frequently preferred. The use of fungicide is the most economical and the most common way along with these strategies. The use of the other two approaches remains limited. Fungicides are synthetic molecules that affect especially fungal growth via cellular processes. These agents prevent the natural compounds from binding their natural targets and inhibit biochemical processes. These important processes 
are composed of nucleic acid metabolism, cytoskeleton, respiration, signal transduction and sterol biosynthesis [9-13]. Currently, the high use of these fungicides, the increased use of aromatic hydrocarbons, and use in common of various fungicides worldwide, led to an increase in the levels of fungicide resistance in fungus [14-16]. Thus, the researchers have focused on the use of alternative agents.

Essential oils of aromatic, fragrant, and medicinal plants are used in diversity in industrial field, with low or high levels of antioxidant and antimicrobial activities. In particular, qualitative and quantitative features are responsible for these activities of essential oils. Essential oil content produced by plants can be similar, as well as show great diversity. It is often observed that the same essential oil is produced as major or minor compound in different plants [17]. Eugenol, kaempferol, and camphor are some of these important plantderived antifungal agents for Fusarium spp. [18-20]. However, majority of the investigations related to antifungal effects of plant derived natural compounds include the usage of the mixtures including plenty of essential oils. Additionally, these researches have been mainly focused on in vitro growth capacity testes and chromatographic tests [21,22]. The limited investigations report the potential antifungal effects of specific-plant derived essential oils [19] with a minimum inhibitory concentration (MIC) of camphor as 1 $\mathrm{mg} / \mathrm{mL}$ in F. graminearum. Similarly, approximately $1 \mathrm{mg} / \mathrm{mL}$ MIC value is reported from different investigations $[18,20]$. These investigations revealed physiological, morphological, genetic, and epigenetic alterations due to the potential antifungal effects of these specific plant-derived essential oils. However, these investigations have also restricted numbers of fungal species. These investigations do not provide detailed information about the precise mechanisms of plant-derived essential oils in inhibiting the radial growth rates of Fusarium spp. The detailed metabolomics, epigenomics, and genomics alterations information related to specific essential oil treatment still miss.

\section{Conclusion}

The increased resistance to common fungicide in $F$. graminearum revealed [16,23] the need for novel disease management strategies. The use of plant-derived essential oil mixtures provide remarkable results related to the antifungal properties of these compounds [17]. However, the composition of chemical molecules vary in plant species, and it is not possible to detect which molecule has the potential antifungal effect on F. graminearum. In this regard, specific essential oil usage seems to be a promising tool in further research related to head blight and crown rot disease management.

\section{References}

1. Özer N, Soran H. Fusarium species of Turkey. Hacettepe Üniversitesi Eğitim Fakültesi Dergisi. 1991; 6: 259-271.

2. Goswami RS, Kistler HC. Heading for disaster: Fusarium graminearum on cereal crop. Mol Plant Pathol. 2004; 5: 515-525. PubMed: https://pubmed.ncbi.nlm.nih.gov/20565626/

3. Yli-Mattila T, Rämö S, Hietaniemi V, Hussien T, Carlobos-Lopez A, et al. Molecular quantification and genetic diversity of toxigenic Fusarium species in Northern Europe as compared to those in Southern Europe. Microorganisms. 2013; 1: 162-174.

4. Parry DW, Jenkinson $P$, McLeod L. Fusarium ear blight (scab) in small grain cereals-a review. Plant Pathol. 1995; 44: 207-238.

5. Windels CE. Economic and social impacts of Fusarium head blight: changing farms and rural communities in the Northern Great Plains. Phytopathology. 2000; 90: 17-21.

PubMed: https://pubmed.ncbi.nlm.nih.gov/18944567/

6. Matny ON. Fusarium head blight and crown rot on wheat \& barley: losses and health risks. Adv Plants Agric Res. 2015; 2: 00039.

7. Desjardins AE, Proctor RH. Molecular biology of Fusarium mycotoxins. Int J Food Microbiol. 2007; 119: 47-50.

PubMed: https://pubmed.ncbi.nlm.nih.gov/17707105/

8. Trail F. For blighted waves of grain: Fusarium graminearum in the postgenomics era. Plant Physiol. 2009; 49: 103-110.

PubMed: https://pubmed.ncbi.nlm.nih.gov/19126701/

9. Dal Bello GM, Monaco Cl, Simon MR. Biological control of seedling blight of wheat caused by Fusarium graminearum with beneficial rhizosphere microorganisms. World J Microbiol Biotechnol. 2002; 18: 627-636.

10. Kretschmer M, Leroch M, Mosbach A, Walker AS, Fillinger S, et al Fungicide-driven evolution and molecular basis of multidrug resistance in field populations of the grey mould fungus Botrytis cinerea. PLoS Pathog. 2009; 5: e1000696.

PubMed: https://pubmed.ncbi.nlm.nih.gov/20019793/

11. Qiana H, Dub J, Chia M, Sunc X, Lianga W, et al. The $Y 137 \mathrm{H}$ mutation in the FgCYP51B protein confers reduced sensitivity to tebuconazole in Fusarium graminearum. Pest Manag Sci. 2018; 74:1472-1477. PubMed: https://pubmed.ncbi.nlm.nih.gov/29274114/

12. Huang C, Gangola MP, Ganeshan S, Hucl P, Kutcher HR, et al. Spike culture derived wheat (Triticum aestivum L.) variants exhibit improved resistance to multiple chemotypes of Fusarium graminearum. Plos One, 2019; 14: e0226695.

13. Demissie ZA, Witte $T$, Robinson KA, Sproule A, Foote SJ, et al Transcriptomic and Exometabolomic Profiling Reveals Antagonistic and Defensive Modes of Clonostachys rosea Action Against Fusarium graminearum. Mol Plant-Microbe Interact. 2020; 33: 842-858. PubMed: https://pubmed.ncbi.nIm.nih.gov/32116115/

14. Gisi U, Sierotzki H, Cook A, McCaffery A. Mechanisms influencing the evolution of resistance to Qo inhibitor fungicides. Pest Manag Sci. 2002; 58: 859-867.

PubMed: https://pubmed.ncbi.nlm.nih.gov/12233175/

15. Brent KJ, Hollomon DW. 'The Future', Brussels: GIFAP, Fungicide resistance in crop pathogens: how can it be managed? 1995; 48.

16. Talas F, McDonald BA. Genome-wide analysis of Fusarium graminearum field populations reveals hotspots of recombination. BMC Genomics. 16: 996.

17. Arif T, Bhosale JD, Kumar N, Mandal TK, Bendre RS, et al. Natural products-antifungal agents derived from plants. JANPR. 2009; 11: 621-638.

PubMed: https://pubmed.ncbi.nlm.nih.gov/20183299/

18. Sefer Ö, Yörük E, Develi ES, Zümrüt IM, Sezer AS, et al. Kaempferol'ün Başak Yanıklığı Etmeni Fusarium culmorum'un Üremesi ve Toksin Üretimi Üzerine Olan Etkileri, SDÜ Ziraat Fakültesi Dergisi. 2017; 12: 24-33.

19. Gazdağlı A, Sefer Ö, Yörük E, Varol Gì, Teker T, et al. Investigation of camphor effects on Fusarium graminearum and $F$. culmorum at different molecular levels. Pathogens. 2018; 7: 90. 
20. Yörük E, Sefer Ö, Sezer AS, Konukcu Z, Develi ES. Eugenol'ün Fusarium culmorum üzerindeki etkilerinin incelenmesi. Iğdır Üniversitesi Fen Bilimleri Enstitüsü Dergisi. 2018; 8: 215-221.

21. Ibrahim GS, Kiki MJ. Chemical Composition, Antifungal and Antioxidant Activity of Some Spice Essential Oils. Int J Life Sci Pharma Res. 2020; 10: 43-50.

22. Mohamed AA, Behiry SI, Ali HM, EL-Hefny M, Salem MZ, et al.
Phytochemical compounds of branches from P. halepensis oily liquid extract and $\mathrm{S}$. terebinthifolius essential oil and their potential antifungal activity. Processes. 2020; 8: 330.

23. Chung WH, Ishii H, Nishimura K, Ohshima M, Iwama T, et al. Genetic analysis and PCR-based identification of major Fusarium species causing head blight on wheat in Japan. JGPP. 74: 364-374. 